\title{
Letter to the editor:
}

Dear Sir,

The article in your March issue, Some Children At Risk in Victoria in the 19th Century, contains a number of factual errors, some of which have appeared in print before and should, I think, be corrected before they are repeated so often as to become ineradicable. Those dealing with the Melbourne Orphanage can be traced to two sources cited by Dr. Judge and Mrs Emmerson: A.W. Greig's 1936 paper in the Victorian Historical Magazine and J.C. Butler's 1951 booklet The First Hundred Years. In some cases your contributors seem to have misread these texts while other mistakes stem from Greig's and Butler's own use of their source material. Greig frankly based much of his essay on the reminiscences of an old lady, Mrs Eleanor Jane McMicking, who, between 1912 and 1922, had written down her recollection of what her parents had told her about their early years in Melbourne and their many charitable activities. Her main purpose was to record her mother's role in the founding of Victoria's first orphanage and this story, although suspect in one or two details, is largely correct. Her mother, Eleanor Nicholson, had arranged for the care of a small group of destitute children as an act of private benevolence in 1849 . Then, as more homeless waifs came to Mrs Nicholson's attention the responsibility was transferred late in 1850 to the St. James' Dorcas Society of which she was a member. The premises were provided, rent free, by the St James' Visiting Society to which her husband, Germain Nicholson, belonged. So far so good, but Mrs McMicking is not so accurate about the earlier history of the Dorcas and Visiting Societies. The erroneous foundation dates she gives, 1842 and 1843 , are faithfully recorded by Greig and repeated by Butler. The latter adds another mistake by assigning the Dorcas Society's custody of the orphans to 1849 , omitting Mrs Nicholson's year of personal responsibility. The two paragraphs on p. 12 of Some Children At Risk introduce further distortions both by omission and commission. May I give a brief outline of the early history of the Melbourne Orphan Asylum, as the institution was known between 1854 and 1926 , so as to set the record straight according to my reading of the documents. I would welcome any further evidence or corrections.

The St. James' Visiting Society was launched on 7 April $1845^{\prime}$ after an attempt to form such a society the previous year had proved abortive ${ }^{2}$. The Dorcas Society was founded a few weeks later in June 1845 to dispense outdoor relief to poor mothers at the time of their confinement ${ }^{3}$. It did not assume its child care function until $1850^{4}$. Its first orphan asylum was part of the St. James' Visiting Society's cottage at the back of the Royal Oak, Queen Street $^{5}$; the orphans were never housed in the Little Collins Street building mentioned by McMicking, Greig and Butler. After two more moves, to Flagstaff Hill and Bourke Street West, the children were transferred late in 1854 to some tents on government land adjoining, not on, the Simpsons' property at Kew $^{6}$. In March 1856 the new Melbourne Orphan Asylum on Emerald Hill was ready to receive up to a hundred children; 89 were admitted in the first month'. When the Asylum moved again, this time to Brighton in 1878 , accommodation was provided there for less than half the average number of children on the institution's books owing to an extensive boarding out programme resolved upon in 1876 and implemented early the next year. Payments for the maintenance of destitute orphan children were made to foster parents and, under certain conditions, to their own widowed mothers ${ }^{8}$. The idea of direct aid to mothers, far from being too radical for acceptance as stated by Dr. Judge and Mrs Emmerson, was adopted by a Special General Meeting of Contributors on the 26 September 1876 and the byelaws were amended accordingly9. It is true that there was some dissension at committee meetings and some battles over details. One defeated motion quoted in full by Butler may have misled your contributors: the proposal that children already in the Asylum should be returned to their mothers ${ }^{10}$. But the scheme of aiding mothers to keep their children instead of having them admitted to residential care was not only adopted but in time ousted foster placements altogether ${ }^{11}$. After the introduction of mothers' benefits paid by the Children's Welfare Department, then of widows' pensions and child endowment, the number of boarded out children on the orphanage's books diminished until the vanishing point was reached in $1948^{12}$.

With respect, I must also object to the contention of Dr. Judge and Mrs Emmerson that "Protestants were less motivated to establish children's homes than Roman Catholics"'. The Protestant Melbourne Orphan Asylum antedated all others by several years; the first in Geelong was the Protestant Orphan Asylum, organized in 1854 and opened the following year and the Immigrants' Aid Society, founded by Protestants in 1853, sheltered more destitute children between 1854 and 1864 than any other institution ${ }^{13}$.

This brings me to the question of the Princes Bridge Industrial School which was conducted for its first four years by the Immigrants' Aid Society. According to Dr. Judge and Mrs Emmerson it began in 1857 on a site adjoining the Victoria Barracks and was conducted for the first 27 years by A.W. Greig's 
father. Greig, the son, is credited with describing the buildings as "totally unsuitable for maintaining children" (p8). There are several mistakes here: the date, the location, the superintendent, the attribution of the criticism about the buildings and, in a way, the object of the censure. It is true that the forerunner of the Princes Bridge Industrial School existed in 1857 on land adjacent to the then nonexistent Victoria Barracks. There had been a school there for the young inmates of the I.A.S's Immigrants' Home since $1855^{14}$ but in 1857 a new building was erected at the Society's expense and later in the year it came under the auspices of the Board of National Education' ${ }^{\text {s }}$.

It catered from 1857 not only for children in the institution with their destitute parents but also for a new intake of deserted children, admitted on the order of a metropolitan police magistrate or the Chief Secretary and maintained at the Government's expense ${ }^{16}$. But this school on the west side of St. Kilda Road was not an industrial school in either of the senses then current. The term was applied to schools under both the National and the Denominational Boards where some vocational instruction was given; the Free Church School at Buninyong and the Warrnambool National School were so designated, for example. ${ }^{17}$ The Immigrants' Home School was not one of these nor was it an industrial school in the second sense of an institution designed to prevent crime by training the children of the "perishing and dangerous classes" to habits of industry, except in so far as all education was thought to have a salutory effect on wayward youth. Before 1860 it was an ordinary elementary school with teachers drawn from amongst the pauper inmates of the Home. ${ }^{18}$

In 1860 after strenuous negotiations with the government the former Institution for Houseless Immigrants (called the Public

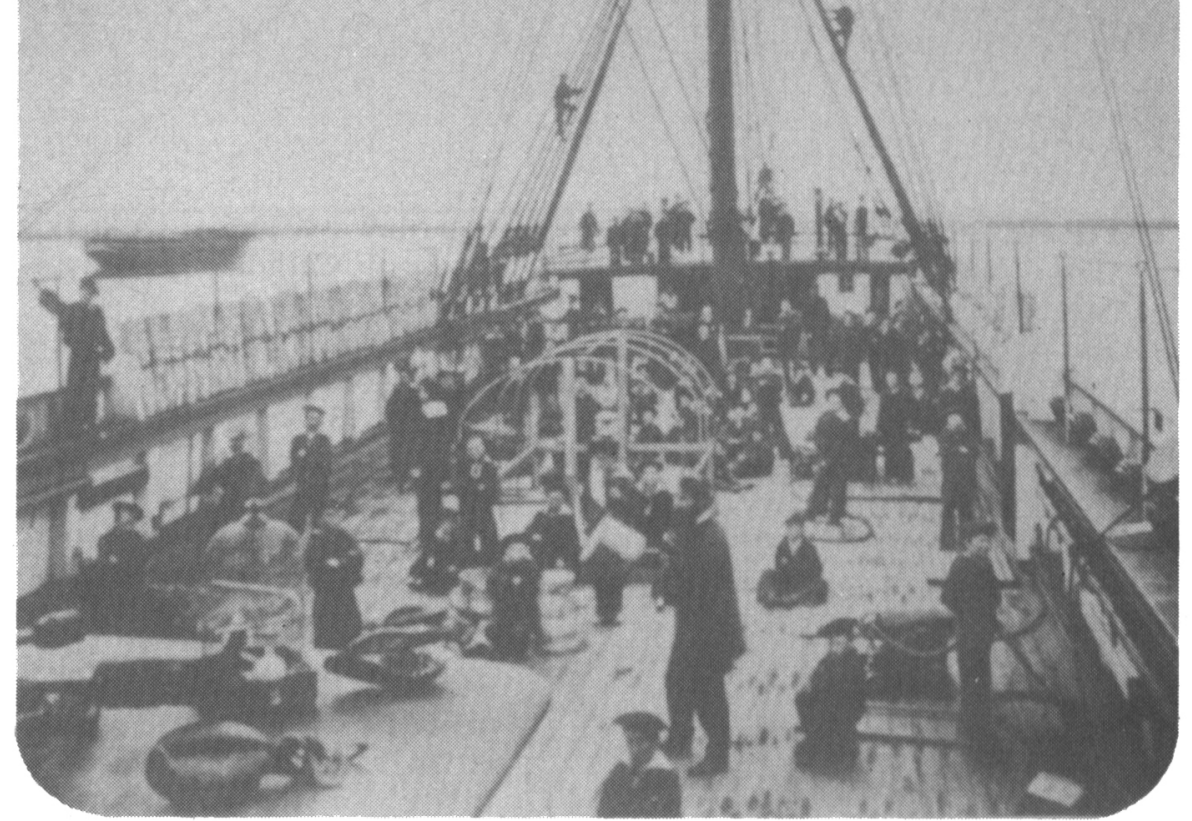

Penal Hulk Deborah?

Houseless Immigrants' Home by Greig) on the opposite, or eastern, side of St. Kilda Road was handed over to the I.A.S. for the purpose of conducting an industrial school until the necessary legislation was passed to enable the government to establish one itself ${ }^{19}$. Juvenile vagrants, prisoners' children and discharged youthful offenders were now to be admitted in much larger numbers. The buildings, which had served as lodgings at a fixed charge for new arrivals from late 1852 to late 1854, had been used in the meantime as temporary barracks for the 40th Regiment until the first portion of the new Victoria Barracks across the road was ready to receive them in $1860^{20}$. The I.A.S. immediately expended a large sum on extensive alterations and improvements to the dilapidated buildings. Then a new brick schoolhouse and other substantial buildings were gradually added $^{21}$. The pauper teachers were replaced by well qualified respondents to an advertisement, the B.N.E. inspector being present when the applicants were interviewed. Industrial training was introducer: : 'n August 1864 the whole estabılsnment was taken over lock, stock and barrel, or rather buildings, children and superintendent, by the Government as its first Industrial School gazetted under the Neglected and Criminal Children $\mathrm{Act}^{23}$. J.T. Harcourt who had been the superintendent of the Immigrants' Home since March 1859 thus became the first Inspector of Government Industrial Schools and Reformatories. He was replaced as secretary and superintendent of the Immigrants' Home by James Saunders Greig who held the post for 27 years after the Industrial School had been removed from the I.A.S's jurisdiction. The remark about unsuitable buildings, cited by A.W. Greig, was made by a government inspector in the 1870's with reference to all the various premises used by the government over the years for reformatories and industrial schools ${ }^{24}$.

One last word, your contributors fail to mention the first reformatory in Victoria under the 1864 Act. It was the penal hulk Deborah, which was proclaimed as such on 27 July. The transfer of boys from Pentridge had begun a month or so earlier ${ }^{25}$.

\section{Sheila Bignell, Vice President, Melbourne Family Care Organization}

\section{References:}

1. MS. Minutes of the St. James' Visiting Society in the possession of the Melbourne Family Care Organization; Port Phillip Herald, 10 April, 1846; 1st Annual Report of St. James' Visiting Society. 
2. P.P.H., 20 August-12 October 1844 passim; P.P.H., 21 November 1848: Donations and Subscriptions to the St. J.V.S. for its first year, viz. April 1845April 1846. Australian Dictionary of Biography Vol. 1, p521, James Grant, Adam Compton Thomson where the formation of the Society in 1844 is recorded but not its demise.

3. St. J.V.S. Minutes, 16 June 1845; P.P.H., 26 June 1845; Port Phillip Patriot, 27 June 1845.

4. 7th Annual Report of St. James' Dorcas Society, July 1852. (This report may be the source of the dating error as it carries the printed date 1850 . Internal evidence clearly supports the inked correction, 1852); St. J.V.S. Minutes JulyDecember 1850 passim; Melbourne Orphan Asylum Register of Inmates.

5. St. J.V.S. Minutes, 29 October 1850; Melbourne Morning Herald, 10 April 1851: 6th Annual Report of St.J.V.S.

6. 7th Annual Report of St. J.D.S. op.cit; Reports of Melbourne Orphan Asylum for year ending July 1854 , for the last 6 months of 1854 and for the year ending December 1855.

7. M.O.A. 5th Annual Report for 1856; Church of England Record 1856 p79.

8. M.O.A. 25th Annual Report for year ending 30 June 1877 .

9. Victoria Government Gazette, 29 September 1876.

10. Butler p10; Argus, 19 and 20 January 1877.

11. M.O.A. Amended Bye-Laws appended to 42nd Annual Report for year ending 30 June 1894.

12. M.O.A. Annual Reports with appended statistics, 1910-19, 1921-2, 1930-1949.

13. Sheila Bignell, Orphans and Destitute Children in Victoria up to 1864, Victorian Historical Magazine, Vol.44, Nos 1 \& 2,
Feb-May 1973. For founding dates of Catholic orphanages see p.14.

14. Denominational Schools Board Correspondence, 55/750 \& $55 / 893,23$ August and 1 October 1855; Argus, 25 October 1855.

15. B.N.E. Correspondence, $57 / 1718 \& 57 / 2022,31$ July and 17 September 1857.

16. B.N.E. 57/1718 op.cit; Chief Secretary's Office Correspondence 57/4476, 24 June 1857 $60 / 3439$, April 1860, passim.

17. B.N.E. $55 / 118 \mathrm{a}$, Jan 1855 ; Victorian Parliamentary Papers 1856-7 Vol.4, Report of D.S.B. for 1855-6.

18. B.N.E. Correspondence 18571860 passim; I.A.S. Annual Report for 1859.

19. Chief Secretary's Office Correspondence, 60/256660/3467, 19 March \& 18 April 1860; Argus, 25 Feb 1860; Geelong Advertiser, 9 June 1860.

20. Ibid.

21. I.A.S. Minutes, 7 September 1861-15 January 1864 passim; Argus 27 December 1862.

22. I.A.S. Minutes 1861-64 passim; Annual Reports 1860-64; B.N.E. $60 / 1975-63 / 7744,16$ November 1860-23 Sept. 1863 passim.

23. V.P.P. 1872, Vol.3, Royal Commission on Industrial and Reformatory Schools 1871; R.W. Willis, The Establishment of Industrial and Reformatory Schools in Victcria .... (Unpublished B.A. Thesis, University of Melbourne 1968).

24. V.H.M. Vol. XVL, No.1, p9; see also V.P.P. 1872 Vol.3 op.cit.

25. C.S.O. 64/2784, 64/5536, 64/8083, Reports of Visiting Justice to Penal Establishments for February, June and July 1864; Statistics of the Colony of Victoria 1864, p.251.

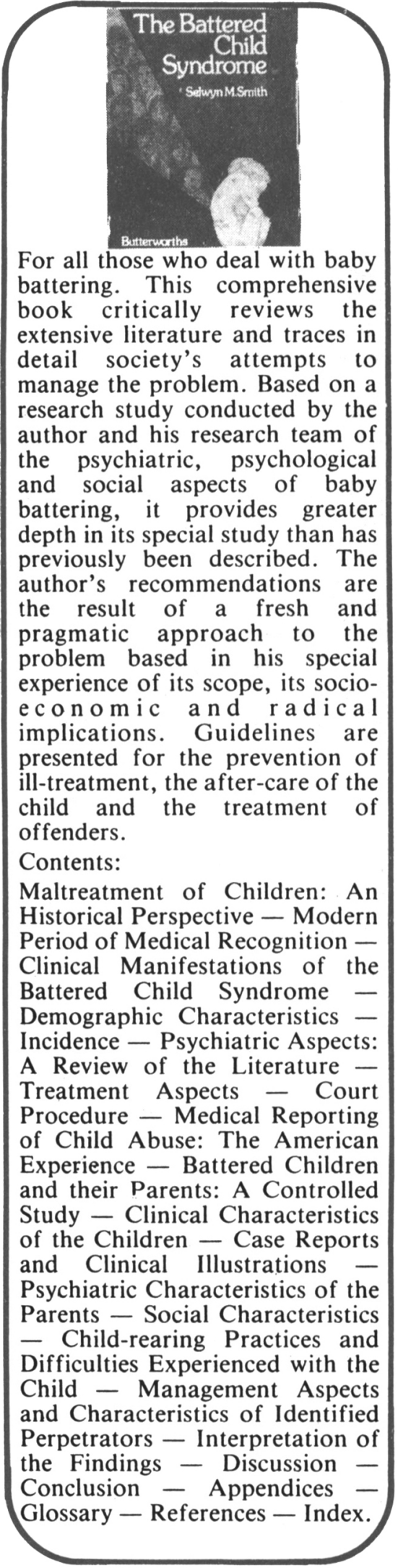

